\title{
A PROTEÇÃO JURÍDICA DE CULTIVARES LEGAL
}

\section{PROTECTION OF VARIETIES}

\author{
${ }^{1}$ Juliana Morais de Carvalho Castiglioni \\ ${ }^{2}$ Nivaldo Dos Santos
}

\section{RESUMO}

Trata-se de um estudo do direito, inovação e sustentabilidade com enfoque em propriedade intelectual na agricultura, sobretudo na análise da Lei de Proteção de Cultivares. O panorama de cultivares registradas no Brasil em 2015 aponta cerca de 1.969, sendo (50) de feijão, arroz (65), cana de açúcar (105) e soja (598), com fortalecimento da pesquisa pública. Por fim, observa-se rupturas na cadeia de inovação nacional com limitação para amplo acesso da sociedade. Portanto, a temática é atual e relevante e envolve o debate sobre políticas de inovação e desenvolvimento agrário, além da soberania alimentar.

Palavras-chave: Propriedade intelectual, Cultivares, Lei de proteção de cultivares

\begin{abstract}
It is a study of law, innovation and sustainability with a focus on intellectual property in agriculture, especially in the analysis of the Plant Variety Protection Act. The panorama cultivars registered in Brazil in 2015 about 1,969 points, and (50) of beans, rice (65), sugar cane (105) and soybeans (598), to strengthen public research. Finally, there are fissures in the national innovation chain with limitation for extended access of the society. So the theme is current and relevant and involves the debate on innovation policies and agricultural development, as well as food sovereignty.
\end{abstract}

Keywords: Intellectual property, Varieties, Law on plant variety protection

\footnotetext{
1 Mestre em Direito Agrário pela Universidade Federal de Goiás - UFG, Jataí, Goiás (Brasil). E-mail: jmcpub@gmail.com

${ }^{2}$ Doutor em Direito pela Pontifícia Universidade Católica de São Paulo - PUC, São Paulo, (Brasil). Professor Titular da Universidade Católica de Goiás, Professor Adjunto da Universidade Federal de Goiás - UFG, Secretário Especial de Ciência e Tecnologia do Instituto Goiano de Direito Ambiental,e Diretor de Desenvolvimento da Associação Goiana dos Advogados. E-mail: nivaldo.santos@ pesquisador.cnpq.br
} 


\section{INTRODUÇÃO}

Na primeira parte um marco conceitual será traçado, seguido pelo panorama de cultivares registrados no Brasil. Depois uma análise sistemática da legislação pertinente, sobretudo com a Lei de Proteção de Cultivares n. 9.456 de 25 de abril de1997. Por fim um estudo de caso se melhoramento participativo da cultivar Arroz BRSGO Serra Dourada.

O trabalho é indutivo, com análise e interpretação de julgados e jurisprudências, além do método de casos. O estudo de caso é produzido e discutido de uma situação real. É um argumento a partir de observação, estudo de documentos e organização de informações técnicas.

Alguns conceitos são fundamentais para o entendimento do tema, como OGMOrganismos Geneticamente Modificados, transgênicos e cultivares. Entende-se como OGM todo organismo que teve seu material genético modificado para obter alguma melhora. Seria o gênero mais amplo, em que os transgênicos recebem um ou mais genes de outro ser vivo e as cultivares são variedades de vegetais com melhoramento do seu próprio genoma (LEITE, 2013).

A questão da adoção dos transgênicos ainda é polêmica. O Brasil é o segundo maior produtor de Organismos Geneticamente Modificados (OGMs) do mundo, perdendo somente para os Estados Unidos. Entretanto, também é o maior consumidor de agrotóxicos ${ }^{1}$ do mundo.

Segundo pesquisa realizada pela consultoria Céleres, o Brasil possui 37,1 milhões de hectares destinados apenas à plantação de transgênicos. Ou seja, mais da metade do território destinado a atividades agrícolas (67,7 milhões de hectares em 2013, conforme dados do IBGE em 2013). Cerca de $88,8 \%$ do cultivo total da soja para a safra 2012/13 é modificado geneticamente no país (AS-PTA, 2013).

O histórico do uso de produtos geneticamente modificados no Brasil traz nuances jurídicos e políticos. A comercialização do produto só foi regulamentada em 1995. O Decreto de Rotulagem $^{2}$ n. 4.680, 24 de abril de 2003, está em vigor e obriga

${ }^{1}$ Há distinções entre cultivares (melhoramento convencional na mesma espécie) e transgênicos ou OGM (engenharia genética em espécies distintas). Mesmo com os avanços nestas técnicas, questiona- se por que o Brasil é o maior consumidor de agrotóxico do mundo. O transgênico demanda mais agrotóxico que uma cultivar? Não é possível generalizar, depende especificamente da espécie. Um fato relevante é que as mesmas empresas multinacionais que vendem as sementes transgênicas, vendem também o agrotóxico determinado para esta semente.

2 O símbolo de transgênicos nas embalagens representa uma forma concreta dos consumidores identificarem produtos com transgenia. 
as empresas produtoras e vendedoras a identificarem na embalagem os alimentos que possuem mais de $1 \%$ de matéria prima geneticamente modificada. Em 2005, foi criada a Lei da Biossegurança n. 11.105 de 24/03/2005, que determinou diretrizes para pesquisa de Biotecnologia no país, e criou a CTNBio- Comissão Técnica Nacional de Biossegurança.

A temática é atual e relevante, envolve o debate sobre políticas de desenvolvimento e questões de soberania alimentar. No dia 5 de março de 2015, a CTNBio foi ocupada por camponeses do Movimento Social Via Campesina, na ocasião estava na pauta a liberação de três novas variedades de plantas transgênicas no Brasil, entre elas, milho e eucalipto. A reunião foi interrompida e a votação adiada.

O resumo geral de plantas geneticamente modificadas aprovadas para comercialização da CTNBio apresenta um domínio das multinacionais. Em dezembro de 2014, o líder em transgênicos autorizados é o milho (21), seguido pelo algodão (12) e pela soja (5). Todas as 38 autorizações são para as multinacionais: Monsanto, Bayer, Syngenta, Dow Agrosciences e Du Pont. Somente a soja (cujo nome comercial é cultivance) é da parceria da BASF com a Embrapa.

A presença nacional no desenvolvimento e comercialização é restrita nesta parceria e no único transgênico do feijão. Somente em 2011, a CTNBio aprovou a produção comercial do primeiro OGM desenvolvido exclusivamente com tecnologia brasileira pela Embrapa. O novo feijão-carioca é resistente ao vírus do mosaic dourado.

O estudo dos transgênicos é amplo, mas não é o foco principal desse trabalho. Foi desenvolvido como contexto para o tema das cultivares e da necessidade de sua proteção jurídica.

O equívoco é comum ao tratar transgênicos e cultivares como sinônimos. Definitivamente são distintos. Assim, após essa breve explanação da polêmica questão de transgênicos, segue um enfoque nas cultivares.

Segundo o MAPA- Ministério da Agricultura, Pecuária e Abastecimento, cultivar significa o resultado de melhoramento em uma variedade de planta que a torne diferente das demais em sua coloração, porte, resistência a doenças por meio de uma nova combinação do seu próprio material genético. A nova característica deve ser igual em todas as plantas da mesma cultivar, mantida ao longo das gerações.

O sistema de proteção de cultivares fundamenta-se na ideia de que os melhoristas devem ser estimulados a criar novas variedades vegetais e de que, para 
tanto, precisam ser recompensados por suas criações. É um sistema que nasceu na Europa, para estimular investimentos privados no melhoramento de plantas, contrapondo-se ao sistema norte-americano de concessão de patentes sobre plantas, e depois se espalhou inclusive para o Brasil, que editou a sua Lei de Proteção de Cultivares (LPC) (SANTILLI, 2009, p. 129).

Assim, conforme disposto no art. $3^{\circ}$, IV da LPC, cultivar representa a variedade de qualquer gênero ou espécie vegetal superior que seja claramente distinguível de outras cultivares conhecidas por margem mínima de descritores, por sua denominação própria, que seja homogênea e estável quanto aos descritores através de gerações sucessivas e seja de espécie passível de uso pelo complexo agroflorestal, descrita em publicação especializada disponível e acessível ao público, bem como a linhagem componente de híbridos.

Por acordo internacional, os países-membros da Organização Mundial do Comércio podem regulamentar a proteção intelectual dos cultivares, por um sistema patentário, um modelo sui generis ou uma combinação de ambos.

Alguns países, como Estados Unidos, Japão, Austrália e Coreia, optaram por um sistema de proteção misto, em que se combinam os modelos de patentes e o de proteção sui generis. Outros adotaram um sistema exclusivamente sui generis, como o Brasil.

Observa-se que essa proteção existe em algumas legislações, como a Plant Patent Act nos Estados Unidos, em 1930, que estabeleceu os direitos de patente aos obtentores de novas variedades de muitas plantas propagadas assexuadamente. Na década de 1950, Alemanha e França positivaram uma proteção sui generis de novas variedades vegetais. "Esse movimento resultou na Conferência de Paris, em 2 de dezembro de 1961, com a criação da União Internacional para a Proteção das Obtenções Vegetais (UPOV, sigla em francês para Union Internacionale pour la Protection des Obtentions Vegetales)” (MAPA, 2011).

Convenção de UPOV é um conjunto significativo de normas subjetivas, entrou em vigor em 1968 e foi revisada em 1972, 1978 e 1991. O Ato de 1978 passou a vigorar em 8 de novembro de 1981 e o Ato de 1991, em 24 de abril de 1998. Dessa forma, há dois atos principais que regulam e estabelecem modelos, sendo que o Brasil optou pelo de 1978.

Os defensores da proteção jurídica das cultivares defendem a modernização das estruturas, a globalização da economia, a valorização do progresso técnico, do 
mercado como indutor do desenvolvimento e do lucro como instigador de avanço tecnológico. $\mathrm{O}$ foco é na maior produtividade, gerando inovação e desenvolvimento.

Dessa forma, associar a proteção de sementes e de cultivares à inovação e à competitividade em prol do desenvolvimento do país é plausível. "No mundo globalizado, o desenvolvimento econômico é baseado, essencialmente, na capacidade de um país gerar, apropriar e aplicar o conhecimento num determinado setor. A riqueza assume formas intangíveis. O capital intelectual das empresas, da sociedade e do Estado passa a ser a base para configurar o grau de competitividade e a segurança alimentar. É nesse espectro que se enquadra o Sistema de proteção de Cultivares” (SANTOS, 2012, p. 174).

\section{PANORAMA DE CULTIVARES NO BRASIL}

Essa parte do estudo apresenta uma análise do panorama das cultivares registrados no Brasil. Segundo o SNPC - Serviço Nacional de Proteção de Cultivares ${ }^{3}$, em janeiro de 2015 há cerca de 1.969 registros de cultivares no Brasil. Sendo 65 registros na denominação arroz, com 74\% dos titulares da Embrapa e Institutos de pesquisa estaduais e empresas nacionais com 12\%. Apenas 14\%, ou 9 titulares do arroz são empresas multinacionais. No caso do feijão, simplesmente não há registros desta denominação por empresas estrangeiras. São 50 registros desta

denominação, sendo $78 \%$ da Embrapa e Institutos de pesquisa estaduais e 22\% dos titulares são empresas nacionais. Ou seja, a totalidade das cultivares de feijão e $86 \%$ das cultivares de arroz registradas no Brasil são nacionais.

Ao analisar a lista de cultivares registrados no Brasil, observa-se que os titulares são brasileiros para denominações de arroz e feijão, bem como o consumo predominante nacional. Por outro lado, produtos voltados para exportação apresentam resultados diferentes, como a cana de açúcar e a soja. Além disso, a taxa de utilização

\footnotetext{
${ }^{3}$ O SNPC disponibiliza uma lista das cultivares registradas (por espécie ) e informa seus respectivos titulares e suas denominações próprias. Essa análise quantitativa foi baseada nestas planilhas de registros. O critério empresa nacional, não pode ser identificado apenas pela denominação da empresa. Aqui foi adotado um critério aproximativo, meramente didático. Com o art. 171 da CF/88 revogado, a definição legal de empresa brasileira de capital nacional ficou em desuso. A empresa estrangeira poderá atuar no território brasileiro de diversas maneiras, dependendo do seu interesse, seja como filial, sucursal, agência ou estabelecimento (sede no estrangeiro);empresa nacional (organizada de conformidade com a legislação brasileira e que mantenha a sede de sua administração no Brasil); participação em sociedade brasileira (acionista ou cotista) ou intermediação: comissão, mandado ou representação comercial; ou ainda joint ventures.
} 
das sementes é bem inferior no feijão (16\%) e arroz (40\%), comparado à soja (65\%) e o milho $(88 \%)$. A cana de reprodução vegetativa utiliza mais clones.

Conforme os dados do SNPC - Serviço Nacional de Proteção de Cultivares, em janeiro de 2015, há 105 registros de cana de açúcar. Sendo 30\% para titulares de empresas nacionais e $30 \%$ para empresas multinacionais. A Embrapa não tem nenhum registro, mas as Universidades Federais e os Institutos de pesquisa estaduais representam $40 \%$ dos titulares, com 42 denominações de cultivares.

Certamente a soja é a denominação com mais registros no SNPC, são 598 registros no total, sendo $35 \%$ para grupos estrangeiros e $30 \%$ para titulares de empresas nacionais. Embrapa com participação em $30 \%$ dos registros e Universidades e Institutos de pesquisa estaduais com apenas $5 \%$.

Assim, ao contrário da lista de plantas transgênicas autorizadas à comercialização pelo CTNBio, no caso das cultivares registradas, há uma grande participação nacional, sobretudo de ICT's - Instituições de Ciência e Tecnologia, as Universidades Públicas e institutos de pesquisa.

Ao analisar a proteção de cultivares, Carvalho destaca justamente o fortalecimento da institucionalidade da pesquisa pública como um todo, dando uma nova conotação para o Sistema Nacional de Pesquisa Agropecuária (que inclui, além da Embrapa, as organizações estaduais de pesquisa agropecuária e as universidades), levando a que a presença nacional no melhoramento genético mantenha-se majoritária.

Certamente a atuação da Embrapa e da pesquisa pública brasileira é determinante no melhoramento de cultivares. Os resultados são referenciais, entretanto nem todo os cultivares registrados são comercializados e disponibilizados aos agricultores. As instituições públicas precisam das empresas de produtores de sementes melhoradas, os responsáveis pelo pagamento de royalties.

Outro caso de sucesso é o de melhoramento genético da cana de açúcar feito pela RIDESA, uma parceria público-privada formada por uma rede de 10 Universidades Federais e mais de 300 empresas sucroalcooleiras.

Além disso, a RIDESA faz parceria com a Petrobrás e desenvolve um grande projeto de pesquisa de variedade de cana de açúcar para produção de etanol de segunda geração, isto é, produção de etanol a partir da celulose da parede celular do bagaço da cana via processo enzimático e bioprocessos com leveduras. Inclusive o 
Melhoramento Genético da Escola de Agronomia da UFG faz parte deste projeto inovador.

Por outro lado, a RIDESA também fez parceria com a multinacional Dupont. As duas variedades mais plantadas de cana de açúcar (RB867515 e RB966928) já foram transformadas em transgênicas ${ }^{4}$ com resistência ao glifosato e à Diatraea, conhecida como a broca da cana (NOVA CANA, 2014).

\section{CARACTERÍSTICAS E SALVAGUARDAS NA LPC}

São cinco os requisitos básicos necessários para a proteção de uma cultivar: novidade, distinção, homogeneidade, estabilidade, além de denominação própria (BULSING et al., 2010, P.259-261):

Assim, a cultivar não pode ter sido oferecida à venda ou comercializada no Brasil, há mais de 12 meses (em relação à data do pedido de proteção); ser claramente distinta de qualquer outra, cuja existência na data do pedido de proteção seja conhecida. A escolha das características que comporão os descritores de cada espécie vegetal leva em conta os traços morfológicos, fisiológicos ou moleculares mais marcantes e possíveis de serem passados a cada geração que a cultivar é multiplicada; O requisito da homogeneidade significa que a cultivar utilizada num plantio deve manter um padrão uniforme das características, levando-se em consideração a sua biologia reprodutiva (autofecundação ou fecundação cruzada) e o seu tipo de propagação (propagação por sementes ou vegetativa). A cultivar deve, ainda, ser estável, ou seja, quando multiplicada por sucessivas gerações de cultivo mantém suas características preservadas. Os requisitos de distinguibilidade, homogeneidade e estabilidade são comprovados através de experimentos específicos conhecidos por Testes de DHE.

Os pesquisadores das ICT's fazem estes Testes de DHE, mas o grande entrave é a burocracia envolvida. Os formulários para pedidos de proteção são três:

\footnotetext{
${ }^{4}$ Apesar das distinções entre cultivares e transgênicos já reiteradas nesse trabalho, esses exemplos da cana da RIDESA e Dupont indicam que parte das cultivares registradas são posteriormente modificadas por engenharia genética e acabam por ser transgênicas também, sobretudo aquelas mais comercializadas (geralmente por produtoras multinacionais). Não há consenso se efetivamente o consumo de agrotóxico foi reduzido com a transgenia.
} 
Requerimento Eletrônico de Pedido, Relatório Técnico e Tabela de Descritores Mínimos da Cultivar. Eles até estão disponíveis no site do SNPC, mas requer ajuda de especialistas para completar o procedimento.

Outro aspecto do procedimento é o prazo para comprovar a estabilidade, muito longo por sinal, variando de acordo com a espécie entre 10 e 30 anos. Além da necessidade de uma amostra viva utilizada na propagação da cultivar ficar disponível ao SNPC, pode ser qualquer parte da planta (sementes, mudas, estacas, meristemas) que tenha capacidade de gerar novas plantas da cultivar protegida.

No Brasil, a proteção vigora a partir da data da concessão do Certificado Provisório de Proteção e tem a duração, em regra, de 15 anos. No caso das árvores frutíferas, árvores florestais, árvores ornamentais e videiras ela se estende para 18 anos.

Assim, a Lei de Proteção de Cultivares- LPC de 1997, introduziu a proteção da propriedade intelectual no campo do melhoramento vegetal, com reflexos em instituições de pesquisa agropecuária e no setor de produção de sementes.

"Esta Lei buscou medidas para evitar a utilização abusiva do direito exclusivo do obtentor e para amenizar os riscos de monopolização da produção de sementes" (ARAÚJO, 2010, p. 58).

Para produzir sementes de cultivares protegidas, inscritas no Serviço Nacional de Proteção de Cultivares (SNPC), é necessário autorização do detentor dos direitos de propriedade intelectual.

A proteção assegura ao obtentor o direito à reprodução comercial da cultivar no território brasileiro (artigo $9^{\circ}$, da Lei no 9.456/1997). Assim, durante o prazo de proteção, fica vedado a terceiros a produção com fins comerciais, o oferecimento à venda ou a comercialização do material de propagação da cultivar, sem autorização do titular do direito.

Quem pratica atos contrários a esse direito de exclusividade, sem autorização do titular, está sujeito às sanções, conforme disposto no artigo 37, da LPC: "fica obrigado a indenizá-lo, em valores a serem determinados em regulamento, além de ter o material apreendido, assim como pagará multa equivalente a vinte por cento do valor comercial do material apreendido, incorrendo, ainda, em crime de violação dos direitos do melhorista, sem prejuízo das demais sanções penais cabíveis". Sendo que a multa pode ser duplicada em caso de reincidências. 
Sobre essa penalidade, entende-se que é uma multa administrativa tendo em vista que o obtentor do direito de proteção da cultivar poderá propor ação civil de perdas e danos. O recebimento da multa é feito pelo próprio SNPC, e está destinada para contribuição da manutenção do respectivo órgão.

Visando salvaguardar o interesse público, a LPC concedeu algumas exceções. Não contraria o direito de propriedade sobre a cultivar protegida aquele que reserve a planta sementes para uso próprio; para pesquisa científica; para uso de pequeno produtor rural ${ }^{5}$. Assim dispõe o art. 10, da referida lei:

Art. 10. Não fere o direito de propriedade sobre a cultivar protegida aquele que:

I - reserva e planta sementes para uso próprio, em seu estabelecimento ou em estabelecimento de terceiros cuja posse detenha;

II - usa ou vende como alimento ou matéria-prima o produto obtido do seu plantio, exceto para fins reprodutivos;

III - utiliza a cultivar como fonte de variação no melhoramento genético ou na pesquisa científica;

IV - sendo pequeno produtor rural, multiplica sementes, para doação ou troca, exclusivamente para outros pequenos produtores rurais, no âmbito de programas de financiamento ou de apoio a pequenos produtores rurais, conduzidos por órgãos públicos ou organizações nãogovernamentais, autorizados pelo Poder Público.

$\S 1^{\circ}$ Não se aplicam as disposições do caput especificamente para a cultura da cana-deaçúcar, hipótese em que serão observadas as

\footnotetext{
${ }^{5}$ A definição de agricultor familiar está definido no art. 3o, da Lei n. 11.326 de 2006, que considera empreendedor familiar rural aquele que pratica atividades no meio rural, com propriedade até 4 (quatro) módulos fiscais, mão-de-obra predominantemente da própria família nas atividades econômicas, tenha percentual mínimo da renda familiar originada de atividades econômicas do seu estabelecimento ou empreendimento, na forma definida pelo Poder Executivo e dirija seu estabelecimento ou empreendimento com sua família. Ademais, o art. 4o, II do Estatuto da Terra (Lei n. 4.504/1964) estabelece como "Propriedade Familiar", o imóvel rural que, direta e pessoalmente explorado pelo agricultor e sua família, lhes absorva toda a força de trabalho, garantindolhes a subsistência e o progresso social e econômico, com área máxima fixada para cada região e tipo de exploração, e eventualmente trabalho com a ajuda de terceiros. Já a definição de pequeno produtor rural é tratado de forma distinta no ordenamento jurídico. Segundo o art. 3o, I da Lei n. 11.428 de 22 de dezembro de 2006, é aquele que, residindo na zona rural, detenha a posse de gleba rural não superior a 50 hectares, explorando-a mediante o trabalho pessoal e de sua família, admitida a ajuda eventual de terceiros, bem como as posses coletivas de terra considerando-se a fração individual não superior a 50 hectares, cuja renda bruta seja proveniente de atividades ou usos agrícolas, pecuários ou

silviculturais ou do extrativismo rural em $80 \%$ (oitenta por cento) no mínimo. Não foi determinado se a área de 4 módulos fiscais está relacionada à area total ou aproveitável.
} 
seguintes disposições adicionais, relativamente ao direito de propriedade sobre a cultivar:

I - para multiplicar material vegetativo, mesmo que para uso próprio, o produtor obrigar-se-á a obter a autorização do titular do direito sobre a cultivar;

II - quando, para a concessão de autorização, for exigido pagamento, não poderá este ferir o equilíbrio econômico-financeiro da lavoura desenvolvida pelo produtor;

III - somente se aplica o disposto no inciso I às lavouras conduzidas por produtores que detenham a posse ou o domínio de propriedades rurais com área equivalente a, no mínimo, quatro módulos fiscais, calculados de acordo com o estabelecido na Lei $\mathrm{n}^{\circ}$ 4.504, de 30 de novembro de 1964, quando destinadas à produção para fins de processamento industrial;

IV - as disposições deste parágrafo não se aplicam aos produtores que, comprovadamente, tenham iniciado, antes da data de promulgação desta Lei, processo de multiplicação, para uso próprio, de cultivar que venha a ser protegida.

Questiona-se o motivo pelo qual estas salvaguardas não são aplicadas no caso da cana de açúcar. Seria uma restrição legal válida? Não malfere os princípios da igualdade perante a lei e da livre concorrência, previstos na $\mathrm{CF} / 88$ ? Sem falar que a restrição nas regras aplicadas somente para a cana não excluíram a propriedade média.

O SEBRAE-GO (2012, p. 10, 11) alerta que somente as legislações relacionadas ao crédito rural utilizam a renda como critério de classificação, as demais usam o critério da área da propriedade rural “(...) e possuem como motriz dessa estratégia a subvenção econômica aos produtores rurais, sem atentar-se para aspectos de viabilidade econômica. Dessa forma, a lei limita-se a priorizar e criar os grupos dos pequenos e mini produtores rurais, cabendo aos normativos para operacionalização do crédito rural a caracterização desses grupos". As normas regulamentas pelos Fundos Constitucionais ${ }^{6}$.

\footnotetext{
${ }^{6}$ Nos relatórios de Programação para 2012 do Fundos Constitucionais de Financiamento do Nordeste, são apresentados quatro grupos de produtores rurais, sendo atribuída faixa de renda a cada porte. Sendo a Receita operacional bruta anual/ renda agropecuária bruta até R\$ 360 mil para mini ou micro produtor rural; entre $\mathrm{R} \$ 360$ mil e $\mathrm{R} \$ 3.600 .000$ para pequeno produtor; até $\mathrm{R} \$ 16$ milhões para
} 
Além disso, "tratamento diferenciado também recebe o pequeno produtor rural, pelo qual se permite a ele produzir e negociar sementes através de doação ou troca com outros pequenos produtores (agricultores familiares, os assentados da reforma agrária e os indígenas)" (SANTOS, 2012, p.182).

Ademais, a proposta estabelece que os agricultores familiares, os assentados da reforma agrária, os indígenas e os integrantes de comunidades locais serão considerados "pequenos produtores rurais" (para fins de exceção ao direito do obtentor), se atendidos todos os requisitos acima. Complementa Santilli (2009, p. 161)

A exigência (prevista na proposta do Poder Executivo) de que o "pequeno produtor rural não detenha, a qualquer título, área superior a quatro módulos fiscais, criará dificuldades para a caracterização de agricultores indígenas e tradicionais, especialmente na região da Amazônia, onde as áreas demarcadas podem exceder os quatro módulos fiscais. O que caracteriza o sistema agrícola tradicional não é a dimensão das terras ocupadas, e sim as formas tradicionais de cultivo e o uso dos recursos agrícolas. As limitações ao uso próprio de sementes, seja em virtude do tamanho da área, seja por causa da renda dos agricultores, ignoram a importância do uso próprio e dos sistemas locais de sementes para a manutenção da diversidade genética e sociocultural no campo.

Assim, o direito de obtenção vegetal reconhece o privilégio (direito) do agricultor de guardar parte de sua colheita para semeadura nas safras seguintes. Ao agricultor é assegurado o direito de reservar e reproduzir sementes para uso próprio, ainda que de variedades protegidas.

A lei prevê, pois, o direito do agricultor de reservar e plantar sementes para uso próprio, em seu estabelecimento ou em estabelecimento de terceiros cuja posse detenha, assim como de usar ou vender como alimento ou matéria-prima o produto obtido do seu plantio (exceto para fins reprodutivos). Ou seja, não pode comercializar as sementes melhoradas, mas somente os grãos.

pequeno-médio produtor; médio produtor entre $\mathrm{R} \$ 16$ milhões e $\mathrm{R} \$ 90$ milhões; e o grande produtor acima desse valor (SEBRAE-GO, 2012). 
A lei estende, portanto, ao pequeno produtor rural o direito de multiplicar sementes, para doação ou troca, exclusivamente para outros pequenos produtores rurais. Complementa Santilli (2009, p. 156 e 157):

Durante a tramitação do projeto de lei no Congresso Nacional, essa foi uma das questões mais polêmicas, pois as organizações da sociedade civil sustentaram arduamente que os pequenos agricultores deveriam ter um tratamento diferenciado não só para a multiplicação de sementes para doação ou troca, mas também para a venda. A venda de sementes acabou, entretanto, sendo excluída do projeto de lei aprovado, e a necessidade de autorização do obtentor (e de pagamento de royalties) para a produção comercial de sementes de variedades protegidas tem trazido enormes dificuldades para que os pequenos agricultores possam produzir as suas próprias sementes e vendê-las a outros pequenos agricultores em mercados locais.

A salvaguarda do uso próprio é causa de ações judiciais, uma vez que é usada como motivo de não pagamento de royalties de cultivares. Ao analisar jurisprudências, o armazenamento de cultivares não é entendido como prova da comercialização. Inclusive a titular da cultivar, como autora, teria o ônus de provar que sua variedade vegetal protegida não fora para fim de uso próprio dos agricultores. Nesse sentido seguem entendimentos do Tribunal de Justiça do Paraná:

APELAÇÃO CÍVEL - LEI DE PROTEÇÃO DE CULTIVARES - SEMENTES ARMAZENAMENTO - AUSÊNCIA DE PROVA DA COMERCIALIZAÇÃO - HONORÁRIOS ADVOCATÍCIOS

- VALOR FIXAdO DENTRO DOS PARÂMETROS LEGAIS - MANUTENÇÃO RECURSO DESPROVIDO. Por inexistir, mesmo na atividade de beneficiamento perpetrada pela requerida, qualquer intuito de mercancia - neste conceito abrangido a exposição à venda, reprodução, importação ou exportação de cultivares, não se pode falar, que tenha havido violação de direitos autorais da autora, sobretudo porque as sementes que foram apreendidas na empresa, pertenciam a terceiras pessoas, que utilizavam-se da prestação de seus serviços. (TJ-PR AC: 6545700 
PR 0654570-0, Relator: Joatan Marcos de Carvalho, Data de Julgamento: 20/07/2010, $7^{\text {a }}$ Câmara Cível, Data de Publicação: DJ: 459 grifo nosso)

Outro aspecto comum nas ações judiciais que tratam da salvaguarda do uso próprio é o seu caráter coletivo. A parte dos agricultores é representada por sindicatos. Observa-se as ações coletivas suspendem as individuais.

AGRAVO DE INSTRUMENTO. PROPRIEDADE INTELECTUAL. ROYALTIES. SEMENTES DE SOJA. SUSPENSÃO DAS AÇÕES INDIVIDUAIS EM DECORRÊNCIA DE AÇÃO COLETIVA. POSSIBILIDADE. RECURSO PROVIDO. (Agravo de Instrumento No 70061360335 , Quinta Câmara Cível, Tribunal de Justiça do RS, Relator: Maria Claudia Cachapuz, Julgado em 01/09/2014. Publicação: Diário da Justiça do dia 04/09/2014)

Ademais há procedentes de habilitação de sindicato de Estado da Federação distinto. Neste sentido segue entendimento do Tribunal de Justiça do Rio Grande do Sul reconhecido pelo Superior Tribunal de Justiça:

PROPRIEDADE INTELECTUAL. AÇÃO COLETIVA. PAGAMENTO DE ROYALTIES. LEI DE PROTEÇÃO DE CULTIVARES. SOJA TRANSGÊNICA. DEFERIMENTO DO PEDIDO DE HABILITAÇÃO DE SINDICATO RURAL SITUADO EM OUTRO ESTADO DA FEDERAÇÃO. 1. É possível a habilitação de sindicato rural situado em outro estado da Federação, haja vista a extensão dos efeitos de abrangência das decisões ao âmbito nacional concedida nos autos do REsp 1.243.386/RS. 2. Ausente qualquer argumento a justificar a modificação do posicionamento adotado, resta mantida a decisão recorrida. RECURSO DESPROVIDO. (Agravo Regimental Nº70053002580, Quinta Câmara Cível, Tribunal de Justiça do RS, Relator: Isabel Dias Almeida, Julgado em 27/03/2013). 
PROCESSO CIVIL. RECURSO ESPECIAL. AÇÃO COLETIVA AJUIZADA POR SINDICATO. SOJA TRANSGÊNICA. COBRANÇA DE ROYALTIES. LIMINAR REVOGADA NO JULGAMENTO DE AGRAVO DE INSTRUMENTO. CABIMENTO DA AÇÃO COLETIVA. LEGITIMIDADE DO SINDICATO. PERTINÊNCIA TEMÁTICA. EFICÁCIA DA DECISÃO. LIMITAÇÃO À CIRCUNSCRIÇÃO DO ÓRGÃO PROLATOR.

1. O alegado direito à utilização, por agricultores, de sementes geneticamente modificadas de soja, nos termos da Lei de Cultivares, e a discussão acerca da inaplicabilidade da Lei de Patentes à espécie, consubstancia causa transindividual, com pedidos que buscam tutela de direitos coletivos em sentido estrito, e de direitos individuais homogêneos, de modo que nada se pode opor à discussão da matéria pela via da ação coletiva.

2. Há relevância social na discussão dos royalties cobrados pela venda de soja geneticamente modificada, uma vez que o respectivo pagamento necessariamente gera impacto no preço final do produto ao mercado.

3. A exigência de pertinência temática para que se admita a legitimidade de sindicatos na propositura de ações coletivas é mitigada pelo conteúdo do art. $8^{\circ}$, II, da $\mathrm{CF}$, consoante a jurisprudência do STF. Para a Corte Suprema, o objeto do mandado de segurança coletivo será um direito dos associados, independentemente de guardar vínculo com os fins próprios da entidade impetrante do 'writ', exigindo-se, entretanto, que o direito esteja compreendido nas atividades exercidas pelos associados, mas não se exigindo que o direito seja peculiar, próprio, da classe. Precedente.

(...) 7. Recursos especiais conhecidos. Recurso da Monsanto improvido. Recurso dos Sindicatos provido.(Recurso Especial No1.243.386 - Rs (2011/0037199-1) Relatora : Ministra Nancy Andrighi. Publicação 26/06/2012).

Por fim, a LPC representa um importante marco regulatório. "O simples fato de existir a LCP constituiu um avanço extraordinário para o negócio agrícola do país” 
(SANTOS, 2012, p. 184). Certamente as salvaguardas são frutos da mobilização social em defesa dos direitos dos agricultores na busca do interesse público.

É mister destacar que houveram tentativas de alteração na LPC. Como o PL 2325/2007 proposto pela Deputada Rose de Freitas (PMDB/ES) e apensos PL 3100/2008 e do PL 6862/2010. Todos arquivados no dia 31 de janeiro de 2015. No dia 12 de fevereiro o pedido de desarquivamento feito pelo Deputado Nilson Leitão (PSDB-MT) foi indeferido por não ser o autor das proposições.

Santilli faz duras críticas a estes projetos de lei, que, segundo ela, representam uma ameaça à agrobiodiversidade e aos direitos dos agricultores, uma vez que pretendem adaptar a atual Lei de Proteção de Cultivares (9.456/1997) à Ata de 1991 da Convenção da UPOV, que permite o estabelecimento de novas restrições aos direitos dos agricultores (de uso próprio das sementes) e proíbe o intercâmbio de sementes e explica as principais propostas de mudanças na LPC, como o aumento do prazo de proteção e do objeto, inclusive produtos derivados (SANTILLI, 2009, p.160).

Permanece o desafio para fortalecer a socioagrobiodiversidade em prol do direito humano ao desenvolvimento. Propostas como: categoria de área protegida voltada para a agrobiodiversidade, com a participação dos agricultores e maior atuação democrática nos processos decisórios sobre políticas (agrícolas, agrárias, ambientais); destinação de um percentual sobre as vendas de sementes a um fundo nacional de repartição de benefícios, gerido com a participação de representantes de agricultores familiares, tradicionais e agroecológicos, destinado a apoiar programas para a conservação on farm (local, ou in situ) da agrobiodiversidade e para a implementação dos direitos dos agricultores. (Santilli, audiência pública na Câmara dos Deputados, 08 de julho de $2010^{7}$ ).

\section{A RELAÇÃO ENTRE CULTIVAR E PATENTES}

Há distinções entre o conceito de cultivar e de patente. O direito do obtentor é uma forma sui generis de propriedade intelectual por apresentar características únicas e particulares, adequadas especialmente ao objeto da proteção: as variedades vegetais.

7 Disponível em: <http://www2.camara.leg.br/atividade-legislativa/comissoes/comissoespermanentes/capadr/audiencias-publicas/audiencias-2010/rap-8-jul-10-juliana> Acesso em fev. 2015. 
O comparativo com cultivar requer uma compreensão complementar do conceito de patente. Esta palavra relaciona-se com os conceitos de descoberta, invenção, privilégio e carta-patente.

Portanto, patente é um título de propriedade intelectual temporária sobre uma invenção (produtos ou processos que atendam aos requisitos de atividade inventiva, novidade e aplicação industrial) ou modelo de utilidade (objeto de uso prático com nova forma ou disposição, suscetível de aplicação industrial e resultante de melhoria funcional). Esse direito é outorgado pelo Estado aos inventores ou autores ou outras pessoas físicas ou jurídicas detentoras de direitos sobre a criação. Em contrapartida, o detentor da patente revela o conteúdo técnico da matéria protegida.

Assim, enquanto para a concessão de patentes são necessários requisitos como novidade, aplicação industrial, atividade inventiva e suficiência descritiva, para a concessão do Certificado de Proteção de Cultivares são exigidos os requisitos de novidade, distinção, homogeneidade, estabilidade e denominação própria (MAPA, 2011).

Assim, a principal diferença entre patente e cultivares é a falta de invenção. Não há uma invenção tal como entendida no regime de patentes, embora se exija uma espécie de intervenção, também chamada de melhoria. Por isso a cultivar é reconhecida como direito melhorista (FONTES, 2012).

A Lei de Propriedade Industrial - LPI, Lei n. 9.279, de 14/5/96 permite que sejam patenteados os micro-organismos transgênicos e os processos (dispositivo no art. 18, III e art. 42, II) e veda o patenteamento de plantas ou de suas partes e de ser vivo (conforme art. 10, IX e art. 18, III).

Dessa forma, outra diferença mais evidente é o objeto em si, “(...) pela Lei de Patentes ou Lei de Propriedade Industrial (Lei n. 9.279/96) são patenteáveis microorganismos modicados e processos, por exemplo: genes resultantes de engenharia genética, e pela Lei de Proteção de Cultivares são protegidas as espécies superiores de plantas, sementes ou mudas." (SANTOS, 2012, p. 178).

Ou seja, o todo ou parte de seres vivos naturais e materiais biológicos encontrados na natureza, ou ainda que dela isolados, inclusive o genoma e o germoplasma de qualquer ser vivo natural ou os processos biológicos naturais, não são considerados invenções, segundo a LPI. Exceto os micro-organismos transgênicos que atendam aos três requisitos de patenteabilidade (novidade, atividade inventiva e 
aplicação industrial) e que não sejam mera descoberta, não são consideradas matérias patenteáveis.

É mister destacar que a lei faz uma ressalva para a possibilidade de patentes de processos ou de transgênicos, mediante intervenção humana direta em sua composição genética, uma característica normalmente não alcançável pela espécie em condições naturais. Desde que não sejam mera descoberta e atendam os requisitos de patentes previstos.

Sendo assim, pode haver casos de cumulação de direitos na propriedade intelectual, como a sobreposição de direitos do registro de cultivar e patentes dessa mesma cultivar com processo de transgenia.

Nesse sentido, segue entendimento do Tribunal de Justiça do Rio Grande do Sul, que destaca a possibilidade de patentes dos micro-organismos transgênicos, do produto e do processo, inclusive de cultivares de soja transgênica quanto à superposição legal na LPC e LPI. Nesse caso, enquanto durar a carta patente poderá ser cobrado royalties de um cultivar transgênico, ainda que para uso próprio, pois não se aplica essa salvaguarda para patentes:

\section{APELAÇÂO CÍVEL. AÇÃO COLETIVA. DIREITO À PROPRIEDADE INTELECTUAL.} SOJA TRANSGÊNCIA. LEI DE PATENTES E LEI DE PROTEÇÃO DE CULTIVARES. RAZÕES DE AGRAVOS RETIDOS AFASTADAS E PRELIMINARES SUPERADAS. (..) Afastamento da disciplina normativa do Código de Defesa do Consumidor, não aplicada ao caso em discussão nos autos. No mérito, ainda que a Lei de Patentes não permita a proteção decorrente de patentes para o todo ou partes de seres vivos, houve expressa exclusão desta proibição em relação aos microorganismos transgênicos (art. 18, inc. III, da Lei de Patentes), justamente porque resultantes de um produto de intervenção cultural, por meio do invento. Possível a extensão dos efeitos da propriedade intelectual sobre micro-organismos transgênicos desde que atendam os critérios próprios à situação jurídica de patenteabilidade - no caso, a novidade, a atividade inventiva e a aplicabilidade à atividade industrial. Circunstância expressamente reconhecida, por certificados próprios, em relação ao produto ora discutido em juízo. Não há como excluir dos efeitos de proteção desta o produto do objeto de patente, por força da proteção conferida pelo art. 42 da Lei $\mathrm{n}^{\circ}$ 9.279/96. A doutrina, na interpretação mais correta da Lei de Patentes acerca de casos de propriedade intelectual, esclarece que o art. 42 da Lei 9.279/96, por meio de seus incisos, protege tanto o produto que é objeto direto da patente, como o processo ou o produto obtido diretamente pelo processo, caso seja este patenteado. Descabe excluir-se o direito de patentes sobre o produto de uma intervenção humana por técnica de transgenia - e que abranja todas as características próprias à proteção -, inclusive quando isto ocorra sobre uma cultivar. E isto, porque ambas as Leis mencionadas são omissas na hipótese de sobreposição de situações. Quando uma variedade é desenvolvida pela técnica da transgenia - podendo, portanto, receber a proteção da Lei de Patentes - e sofre, posteriormente, uma melhora por via biológica, recebendo o certificado de cultivares, em tese, tem-se situação de 
duplicidade de proteção, algo que estaria vedado pelas disposições da UPOV referente à Convenção de 1978. (...)Não há, portanto, como se pretender a aplicação de disposições normativas da Lei de Proteção de Cultivares para o caso em comento, na medida em que diversa é a proteção jurídica identificada. (...) Com relação ao percentual de royalties estabelecido, a desproporção é apontada ainda na inicial, por meio de..." seja judicialmente estabelecido percentual não abusivo para adequadamente indenizar as demandadas, em índices que variam entre 0,06\% a 0,10\% sobre o valor da soja transgênica comercializada, preferindo o menor índice pelas razões anotadas " (...).Não há que se falar em abusividade quando negociados entre entidades representantes de ambas as partes royalties em percentual $(2 \%)$ proporcional à prática de mercado internacional, sem que demonstrada efetiva abusividade de cobrança. (...) À unanimidade, desacolheram os agravos retidos e afastaram as preliminares. No mérito, por maioria, deram provimento ao recurso, vencido o desembargador Jorge Luiz Lopes do Canto. (TJ-RS - AC: 70049447253 RS , Relator: Maria Claudia Cachapuz, Data de Julgamento: 24/09/2014, Quinta Câmara Cível - Serviço de Apoio Jurisdição, Data de Publicação: Diário da Justiça do dia 02/10/2014).

É mister destacar que o voto da relatora Maria Claudia Cachapuz na jurisprudência citada, tratou da possibilidade de dupla proteção dos direitos de exclusiva (patentes e cultivares). A relatora explica que a sentença de $1^{\circ}$ grau dispõe sobre a opção no ordenamento jurídico de não aderência a uma dupla proteção de direitos de propriedade de forma exclusiva, firma tal convicção sobre uma situação de sobreposição de legislaçães: "O Brasil, mesmo pinçando aspectos das duas Atas (78 e 91), optou pela revisão de 1978 que proíbe explicitamente a dupla proteção dos direitos de exclusiva". Essa sentença usou, inclusive, pesquisa desenvolvida pelos pesquisadores Charlene Maria Coradini de Avila Plaza e Nivaldo dos Santos, que consideraram "(...) a prática ostensiva da sobreposição de exclusiva entre patentes e cultivares que funcionaliza proteções diversas no mesmo objeto imaterial, ilegal e inconstitucional, porque colide com as funcionalidades específicas dos sistemas normativos que regulamentam a matéria e desequilibram os sistemas civil- constitucional" (SANTOS e PLAZA, 2010). Certamente esses argumentos embasaram o voto vencido do desembargador Jorge Luiz Lopes do Canto, que citou Juliana Santilli e reforçou que a Ata UPOV de 1978 resguardava o denominado privilégio do agricultor e vedava a dupla proteção. 
Entretanto, a relatora apresentou outra visão da doutrina ${ }^{8}$ e alegou a possibilidade de superposição legal. Prevaleceu no julgamento esse entendimento, que quando uma variedade é desenvolvida pela técnica da transgenia - podendo, portanto, receber a proteção da Lei de Patentes - e sofre, posteriormente, uma melhora por via biológica, recebendo o certificado de cultivares, em tese, tem-se situação de duplicidade de proteção.

Portanto, essa interpretação da jurisprudência revela a pertinência do debate tratado nesse trabalho, revela ainda que o poder judiciário utilizou e citou doutrinadores que embasam o presente estudo.

Além disso, a burocracia do INPI é ainda maior ao tratar de patentes de transgênicos ou de processos biológicos, pois o requerente deve informar a data da autorização do CGEN para o cesso ao patrimônio genético e a origem do material genético nacional, conforme a Resolução do INPI n. 134/2006. Deve ainda fazer o depósito do material biológico, apresentar um descritivo detalhado, contendo as

${ }^{8}$ Segundo Barros (2012, p.165), “Se uma patente é concedida, o titular do produto ou processo patenteado goza de ampla gama de direitos exclusivos, conferindo ao seu titular o direito de impedir terceiro, sem o seu consentimento, de produzir, usar, colocar à venda, vender ou importar." 
propriedades imprescindíveis da matéria viva necessárias à sua completa descrição, de acordo com as tecnologias inerentes à respectiva matéria considerada relevante para sua perfeita caracterização. O depósito, na forma de cultura viável, deve acompanhar- se de descrição caracterizadora diferencial da matéria viva, nos planos morfológico, físiológico e/ou bioquímico.

O depósito será também acompanhado da descrição dos meios e métodos ideais de cultivo da matéria viva in vitro, além da listagem de sequências biológicas (todo pedido de patente que descreva uma sequência de nucleotídeos ou aminoácidos deverá conter - além do relatório descritivo, reivindicações, desenho e resumo, uma seção separada chamada Listagem de Sequências, imediatamente após as reivindicações).

\section{O CASO DO ARROZ BRSGO SERRA DOURADA}

O arroz (Oryza sativa L.) é uma das mais antigas espécies cultivadas, ocupando aproximadamente $10 \%$ do solo agricultável do planeta. São basicamente três ecossistemas principais de arroz: terras altas, várzeas úmidas e irrigado por inundação.

O arroz de terras altas (ou arroz aeróbico) é sistema de produção em terras que depende do regime de chuva. Frequente cultivado em 17 milhões de hectares no mundo, sendo Ásia (62\%), na América Latina (22\%) e na África (16\%). No Brasil, a área plantada com arroz de terras altas é de 1.797.707 hectares concentrada nas regiões Centro-Oeste, Mato Grosso e Goiás representando 43,3\% da área total cultivada com esse produto; Nordeste, Piauí e Maranhão (37,8\%); e Norte, Pará e Rondônia com 18,9\% (BARRIGOSSI et al, 2004).

Assim, os pesquisadores da Embrapa Arroz e Feijão fazem um alerta: "Muitas cultivares melhoradas usadas em monocultivo não possuem mecanismos ecológicos de defesa suficientes para tolerar os surtos de pragas. As perdas de produção devido às pragas ainda são elevadas, embora o consumo de agrotóxicos tenha aumentado em escala mundial" (BARRIGOSSI et al, 2004, p. 4).

Nesse contexto, surgiu a parceria na pesquisa pública entre a Universidade Federal de Goiás (UFG), juntamente com a Secretaria de Agricultura, Pecuária e Abastecimento do Estado de Goiás (SEAGRO) e a Embrapa para "uma proposta de intervenção nas comunidades de pequenos produtores, desenvolvendo, validando e difundindo, de forma participativa, novas cultivares de arroz de terras altas, além de 
conhecimentos específicos, visando a sustentabilidade do cultivo do arroz como uma atividade econômica. A cultivar BRSGO Serra Dourada representa o primeiro resultado concreto dessa parceria" (MELO et al, 2009, s/p).

A sustentabilidade da cultura do arroz de terras altas em ambiente de pequenos produtores tem demandado cultivares com características compatíveis com uma agricultura com baixos investimentos em insumos. Em geral, cultivares com maior eficiência na utilização dos nutrientes do solo, maior vigor inicial, maior capacidade de competição com plantas daninhas e maior resistência a doenças são, nesse caso, preferidas. Em Goiás, por exemplo, cerca de $70 \%$ dos estabelecimentos rurais são caracterizados como de agricultura familiar, nos quais a produção de arroz de terras altas aparece entre as suas principais atividades (IBGE, 2006). (...) caracteriza-se pela utilização de baixo nível de tecnologia, pequeno poder de comercialização e custos de produção elevados, tornando a agricultura familiar cada vez menos produtiva (MELO et al, 2009, s/p).

A metodologia usada foi a chamada melhoramento participativo (VERNOOY, 2003), consiste em envolver os agricultores desde o início do processo, participando de todas as fases, principalmente durante o processo de seleção das linhagens. Assim, são obtidas cultivares adaptadas a ambientes específicos e com características que atendam à demanda dos agricultores, pois trabalham com toda a comunidade, pesquisadores de diversas áreas, extensionistas e associações de agricultores.

O melhoramento participativo é considerado uma das estratégias de uso e conservação da diversidade genética em comunidades agrícolas, estabelecidas pelo Plano de Ação Global para Segurança Alimentar da Organização o das Nações Unidas para a Alimentação e a Agricultura (MORAIS, 2007).

A pesquisadora, professora Dra. Patrícia Melo da UFG afirma que este projeto é enriquecedor. Foi feita uma parceria, em que a Embrapa Arroz e Feijão desenvolveu o germoplasma, do cruzamento simples em 1995 da cultivar Katy e Confiança (da origem IAC 164 e Rio Verde). Com a geração F1-F4 entre 1997 e 1998 semeadas em terras altas, passando pelo desbaste, seguido pela individualização até a fase de maturação e seleção de plantas de cada família. Em 2000/2001 foram feitos o Ensaio de Observação de Linhagens, no próximo ano o Ensaio Preliminar de Rendimento, até chegar na linhagem promissora BRA 01653. Foram feitos Ensaios 
Regionais de Rendimento em 2002-2003 nos Estados de Goiás, Minas Gerais, Roraima, Pará e Piauí.

A segunda fase foi do Programa de Melhoramento Participativo de arroz de terras altas. Os ensaios de Valor e Cultivo de Uso (VCU) foram realizados com os pequenos produtores do município de Rubiataba e no Assentamento Canudos (Palmeira de Goiás e Guapó, ambos em Goiás). Em 2007 chegou-se na obtenção da semente melhorista, com qualidade do grão e resistência à brusone. Finalmente em 2008, sementes básicas foram produzidas e 1,5 toneladas de sementes genéticas foram multiplicadas. Depois do VCU e DHE (Teste de Distinguibilidade, Homogeneidade e Estabilidade), a cultivar BRSGO Serra Dourada foi registrada em 2010 no SNPC pela equipe especializada da Embrapa.

O registro de cultivar é regional, ou seja, somente naquela região (condições climáticas e tipo de solo) são garantidas as características melhoradas. Inicialmente ele foi registrado para Goiás, em seguida a recomendação foi estendida para Minas Gerais, Mato Grosso, Tocantins, Maranhão e São Paulo.

Essa parceria foi formalmente concretizada em forma de contrato, com cláusulas de confidencialidade, proteção de propriedade intelectual dividida entre $60 \%$ com Embrapa e 20\% UFG e SEAGRO, respectivamente. Há previsão de royalties, sendo $50 \%$ para Embrapa e 25\% para cada uma das demais.

A pesquisadora melhorista dessa parceria, professora Dra. Patrícia Melo da UFG, acredita e aposta nesse cultivar, sendo que seu registro como produto técnico além de diferencial no seu currículo lattes já a ajudou em edital de bolsas. Ela contribuiu na distribuição dessas sementes para comunidades tradicionais e pequenos agricultores e tem esperança de um dia ver ampliado o acesso. A professora defende o retorno em royalties, não com uma visão individualista, mas como contraprestação capaz de dar continuidade às pesquisas, que requer investimento constante em reagentes e equipamentos.

Desde 1995 (quando ocorreu o cruzamento) até o registro em 2010, foram

15 anos de pesquisa. A média de comercialização para cultivares é de 7 anos para milho híbrido, 12 anos para feijão e arroz e até 35 anos para o café. Apesar do sucesso na parceria e das vantagens do arroz BRSGO Serra Dourada, este cultivar ainda não foi comercializado em escala por uma empresa produtora de sementes, a responsável pelo pagamento de royalties. 
Ou seja, a amostra viva está guardada e as sementes do melhoramento participativo ainda não estão disponíveis para o mercado, não há o acesso dos agricultores. A lista de cultivares registrados pode até demonstrar um bom rendimento da pesquisa pública, mas falta concluir a cadeia produtiva, poucos da lista são realmente comercializados. A tentativa de participar de outras políticas públicas como a Lavoura Comunitária, que distribui sementes e insumos para pequenos agricultores de Goiás foi frustrada, por motivos de licitação o governo goiano não utilizou o arroz BRSGO Serra Dourada.

Cabe um questionamento a respeito do processo licitatório de tecnologias socioambientais. Certamente seria caso de dispensa. Uma interpretação sistemática da Lei n. 8.666 de 21/06/1993, c/c a Lei Estadual de Goiás n. 17.928, de 27/12/ 2012 pode encontrar uma alternativa viável para esse desafio. Afinal, o Art. 24, XXV, da Lei de Licitações, estabelece caso de dispensa de licitação na contratação realizada por Instituição Científica e Tecnológica - ICT ou por agência de fomento para a transferência de tecnologia e para o licenciamento de direito de uso ou de exploração de criação protegida.

Além disso, uma saída para compra pelo Estado de sementes das cultivares como o BRSGO Serra Dourada seria a atuação mais efetiva do Estado como incentivador, papel constitucional previsto no art. 174, da CF/88.

Assim, o Estado (como agente normativo e regulador da atividade econômica), pode interferir na ordem econômica para reprimir o abuso do poder econômico, fiscalizar e incentivar determinadas atividades econômicas. Sendo que a lei estabelecerá as diretrizes e bases do planejamento do desenvolvimento nacional equilibrado, o qual incorporará e compatibilizará os planos nacionais e regionais de desenvolvimento.

Esse dispositivo constitucional permite, pois, a prática pelos Estados e Municípios de concessão de incentivos fiscais, através de subsídios, com a redução da base de cálculo de tributos, ou isenções de tributos em prol do desenvolvimento de uma atividade econômica em uma determinada região.

No caso em questão, o Estado de Goiás poderia incentivar produtores de sementes a comercializar cultivares como o arroz Serra Dourada por meio de uma Chamada Pública com redução na base do imposto sobre circulação de mercadorias nesse caso concreto. 
Para tanto, deveriam ser cumpridos os requisitos legais previsto na Lei Complementar n. 101, de 4 de maio de 2000, conforme dispõe seu art. 14 ${ }^{\text {o: }}$ "A concessão ou ampliação de incentivo ou benefício de natureza tributária da qual decorra renúncia de receita deverá estar acompanhada de estimativa do impacto orçamentário-financeiro no exercício em que deva iniciar sua vigência e nos dois seguintes, atender ao disposto na lei de diretrizes orçamentárias (...)”.

Ao analisar políticas públicas análogas que poderiam concretizar esse poder de compra do Estado voltado para incentivo de tecnologias socioambientais, encontramos o exemplo do compra de alimentos da agricultura familiar para a merenda escolar. Seguem mais informações dessa alternativa que pode ser adaptada para políticas específicas na proteção e transferência de tecnologias verdes.

O Programa Nacional de Alimentação Escolar - PNAE prevê o uso de no mínimo $30 \%$ dos recursos repassados pelo Fundo Nacional de Desenvolvimento da Educação para a alimentação escolar, na compra de alimentos da agricultura familiar para serem servidos nas escolas da rede pública de ensino.

Segundo o MDA, a aquisição de gêneros alimentícios é realizada, sempre que possível, no mesmo município das escolas, priorizando os assentamentos de reforma agrária, as comunidades tradicionais indígenas e comunidades quilombolas. As escolas poderão complementar a demanda entre agricultores do território rural, estado e país, nessa ordem de prioridade. A aquisição dos produtos da agricultura familiar poderá ser realizada por meio de Chamada Pública, dispensando procedimento licitatório (MDA, 2015).

Este programa apresenta vantagens como: para o agricultor familiar, a lei abre mais uma alternativa de comercialização, diversificação e geração de renda; para os alunos da rede pública de ensino, é a garantia de alimentos e hábitos alimentares saudáveis, contribuindo para o desenvolvimento dos alunos; para os municípios, significa o fortalecimento da cadeia da produção à comercialização e a geração de emprego e renda, fortalecendo a economia local (MDA, 2015).

Assim, o PNAE representa sustentabilidade também na Administração Pública, foi um grande avanço para comercialização dos alimentos produzidos por agricultores familiares. Entretanto, ainda há o gargalo de comercialização e distribuição de cultivares como esse arroz, inclusive com facilidades no processo licitatório. 
Apesar do arroz Serra Dourada ter contado com apoio do MDA (no programa Alimenta Mais, com crédito rural para melhoramento genético e infraestrutura na agricultura familiar), representa mais um desafio para as políticas públicas superar a dificuldade na comercialização para um acesso ampliado de tecnologias verdes.

Por fim, esse é um caso de tecnologia social, um melhoramento participativo. "BRSGO Serra Dourada é uma cultivar de arroz de terras altas desenvolvida para a agricultura familiar, com bom potencial produtivo, medianamente resistente à brusone e com boa qualidade de grão" (MELO et al, 2009, p. 1).

Portanto, após todo o estudo histórico da modernização do campo, seguido pelo debate ideológico na proteção de sementes e de cultivares, esse caso do arroz Serra Dourada é emblemático. Desconstrói, de certa forma, o argumento contrário à pesquisa e à inovação no melhoramento de cultivares e uma possível exclusão dos direitos do pequeno agricultor nesse processo. $\mathrm{O}$ melhoramento participativo, assim, representa uma alternativa ao empasse, pois o agricultor familiar pode e deve ter acesso ao material melhorado. $\mathrm{O}$ pequeno agricultor tem o direito de ter acesso às tecnologias socioambientais e melhorar a qualidade de suas sementes. Afinal, a abrangência do uso de sementes crioulas ainda é restrito e a realidade de mercado do agricultor familiar necessita do acesso à cultivares melhorados para sua lavoura ou acabará comprando grãos na mercearia mais próxima.

\section{CONCLUSÕES}

Os dados de cultivares registrados no Brasil demonstram uma grande participação da pesquisa pública representada pela Embrapa, Universidades Federais e Estaduais e pelos Institutos de Pesquisas como obtentores. Entretanto, a realidade do mercado é diferente. O gargalo está na produção dessas cultivares, poucas cultivares registradas estão efetivamente no mercado para uso dos agricultores. A comercialização de sementes de cultivares transgênicos ainda é concentrada nas multinacionais.

\section{REFERÊNCIAS}

ARAÚJO, José Cordeiro. A Lei de Proteção de cultivares: análise de sua formulação e conteúdo. Brasília : Câmara dos Deputados, Edições Câmara, 2010. 137 p. (série memória e análise de leis; n. 1) 
AS-PTA Agricultura Familiar e Agroecologia. Boletim 634 de 28 de junho de 2013. Disponível em: <http://aspta.org.br/campanha/634-2/.> IN: FERREIRA, JOANA. Brasil é o segundo maior produtor de OGMs do mundo. Epochtimes, publicado em 19/06/2013.

BARRIGOSSI, José Alexandre Freitas; LANNA, Anna Cristina; FERREIRA, Evane. Circular Técnica Embrapa n. 67. Agrotóxicos no Cultivo do Arroz no Brasil: análise do consumo e medidas para reduzir o impacto ambiental negativo. Santo Antônio de Goiás, GO Dezembro, 2004.

BRASIL, Lei n. 9.456, de 25 de abril de 1997. Brasília, 25 de abril de 1997; 1760 da Independência e 109o da República.

.Ministério da Agricultura, Pecuária e Abastecimento MAPA. Secretaria de Desenvolvimento Agropecuário e Cooperativismo Proteção de Cultivares no Brasil. Brasília: Mapa/ACS, 2011.

\begin{abstract}
.Ministério da Agricultura, Pecuária e Abastecimento.
Plano setorial de mitigação e de adaptação às mudanças climáticas para a consolidação de uma economia de baixa emissão de carbono na agricultura : plano ABC (Agricultura de Baixa Emissão de Carbono) - Brasília : MAPA/ACS, 2012. BULSING, A. C. ; AVIANI, D. M. ; PACHECO, L. G. A. ; MACHADO, R. Z. . Proteção de Cultivares. In: Luiz Otávio Pimentel. (Org.). Curso de Propriedade Intelectual e Inovação no agronegócio. 2ed.EaD: UFSC, 2010, v. 1, p. 258-273. FONTES, André R. C. Cultivares sob a propriedade intelectual. In: PLAZA, Charlene Maria Corandini et al. (Coord.). Propriedade intelectual na agricultura. Belo Horizonte: Fórum, 2012. p. 51-63.
\end{abstract}

LEITE, Débora Silva; MUNHOZ, Leticia Leite. Biotecnologia e melhoramento das variedades de vegetais: Cultivares e Transgênicos. Veredas do Direito: Direito Ambiental e Desenvolvimento Sustentável, v. 10, n. 19, p. 23, 2013.

MELO, Patrícia Guimarães; MORAIS, Orlando Peixoto; DINIZ, Jairton de Almeida; LOBO, Valácia Lemes; BRESEGGHELLO, Flávio; FONSECA, Jaime Roberto; CASTRO, Adriano Pereira; BASSINELLO, Priscila Zaczuk; CASTRO e Emílio da Maia. BRSGO Serra Dourada: Cultivar de Arroz para a Agricultura Familiar de 
Goiás. Comunicado Técnico n. 177, Santo Antônio de Goiás, GO, Dezembro, 2009. MENEGHELLO, Geri Eduardo e PESKE, Silmar Teichert. A grandeza do negócio de sementes de soja no Brasil. Seednews mês jul/ago 2013 - Ano XVII - n. 4. Disponível em:<http://www.seednews.inf.br/_html/site/content/reportagem_capa/imprimir.php?i d=153> Acesso em: abr. 2015.

MORAIS, Orlando Peixoto. Cruzamentos entre cultivares de arroz adaptadas à agricultura familiar. In: Embrapa Arroz e Feijão-Artigo em anais de congresso (ALICE). In: Anais Congresso Brasileiro de Melhoramento de Plantas, n.4, São Lourenço: Sociedade Brasileira de Melhoramento de Plantas, 2007.

NOVA CANA. Site institucional. Disponível em: $<$ http://www.novacana.com/n/cana/variedades/variedades-rb-respondem-plantio- cana191114/> Acesso em: set. 2014.

SANTILli, Juliana. Socioambientalismo e novos direitos. Proteção juridical à diversidade biológica e cultural. São Paulo, Peirópolis, 2005.

. Agrodiversidade e direitos dos agricultores. São Paulo: Peirópolis, 2009.

- A Lei de Sementes brasileira e os seus impactos sobre aagrobiodiversidade e os sistemas agrícolas locais e tradicionais. Boletim do Museu Paraense Emílio Goeldi. Ciências Humanas, v. 7, n. 2, p. 457-475, maio-ago. 2012. 
SANTOS, Nilvaldo dos; PLAZA, Charlene Coradini de Ávila. Interpenetração de direitos e proteção em propriedade intelectual: $O$ caso das patentes e invenção e cultivares, Anais do XIX Encontro Nacional do CONPEDI, 2010.

SANTOS, Nivaldo dos. O sistema de proteção das cultivares e desenvolvimento sustentável. 1996 IN: PLAZA, Charlene Maria C e NERO, Patrícia Aurélia Del Coordenadoras. Proteção Jurídica para as Ciências da Vida - Propriedade Intelectual e Biotecnologia. São Paulo: IBPI - Instituto Brasileiro de Propriedade Intelectual, 2012. p. $173-2000$.

SEBRAE-GO. Perfil do Produtor Rural, série estudos e pesquisas. jul. 2012. VERNOOY, R. Semillas generosas: mejoramiento participativo de plantas. IDRC, Ottawa, Canadá, 2003. 